\title{
Intramuscular uptake of tranexamic acid during haemorrhagic shock in a swine model
}

\author{
Håkon Kvåle Bakke1,2,3* , Ole Martin Fuskevåg ${ }^{4}$, Erik Waage Nielsen ${ }^{5,6,7,8}$ and Erik Sveberg Dietrichs $s^{9,10}$
}

\begin{abstract}
Background: Tranexamic acid (TXA) reduce mortality in bleeding trauma patients, with greater effect if administered early. Serum concentrations above $10 \mu \mathrm{g} / \mathrm{mL}$ are considered sufficient to inhibit fibrinolysis. Normally administered intravenously (i.v.), TXA can also be administered intramuscularly (i.m.). This could be advantageous in low resource and military settings, if sufficient serum concentrations can be reached in shocked patients with reduced muscular blood perfusion. Accordingly, we aimed to: (1) Determine the impact of shock on the pharmacokinetics of i.m. TXA, and (2) Compare the pharmacokinetics of i.v. versus i.m. TXA in ongoing shock.

Materials and methods: In a prospective experimental study, $N=18$ Norwegian landrace pigs (40-50 kg), utilised in a surgical course in haemostatic emergency surgery, were subjected to various abdominal and thoracic trauma. After $1 \mathrm{~h}$ of surgery the animals were given $15 \mathrm{mg} / \mathrm{kg}$ TXA either i.v. or i.m. A control group without injury, or surgery, received intramuscular TXA. Blood samples were drawn at 0, 5, 15, 25, 35, 45, 60 and 85 min. The samples were centrifuged and analysed with liquid chromatography-tandem mass spectrometry (LC-MS/MS) for TXA serum-concentrations.
\end{abstract}

Results: In shocked pigs, i.m. administration resulted in a mean maximum serum concentration $\left(C_{\text {max }}\right)$ of $20.9 \mu \mathrm{g} / \mathrm{mL}$, and i.v. administration a $C_{\max }$ of $48.1 \mu \mathrm{g} / \mathrm{mL}$. $C_{\max }$ occurred $15 \mathrm{~min}$ after i.m. administration and $5 \mathrm{~min}$ after i.v. administration. In non-shocked swine, i.m. administration resulted in a $C_{\max }$ of $36.9 \mu \mathrm{g} / \mathrm{mL}$ after $15 \mathrm{~min}$. In all groups, mean TXA serum concentrations stayed above $10 \mu \mathrm{g} / \mathrm{mL}$ from administration to end of experiments.

Conclusions: I.m. administration of TXA in shocked pigs provides serum concentrations associated with inhibition of fibrinolysis. It may be an alternative to i.v. and intraosseous administration during stabilisation and transport of trauma patients to advanced medical care.

Keywords: Injury, Trauma, Bleeding, Coagulation

\section{Background}

Tranexamic acid (TXA) has been shown to reduce mortality in bleeding trauma patients [1]. As a synthetic lysine analogue, it works by inhibiting the activation of plasminogen to plasmin, and thereby fibrinolysis, thus enhancing clot stability and improving haemostasis [2]. In vitro studies have suggested that effective serum

*Correspondence: hakonkvalebakke@gmail.com

${ }^{1}$ Department of Anaesthesia and Critical Care, University Hospital of North Norway, 9038 Troms $\varnothing$, Norway

Full list of author information is available at the end of the article concentrations are in the range of 10-17.5 $\mu \mathrm{g} / \mathrm{mL}$ [3-5]. The effect on mortality is time-dependent, with a $10 \%$ reduction in effect for every 15 min delay, and possibly with adverse effect if administered after more than $3 \mathrm{~h}[6$, 7].

While TXA normally is administered intravenously (i.v.), it has been established that the intramuscular (i.m.) route is a feasible alternative. Absorption after iv. administration is faster, with higher peak serum concentrations $\left(\mathrm{C}_{\max }\right)$ than i.m. administration [8]. However, in certain environments i.m. administration would be advantageous. For example, combat medicine, or in low resource original author(s) and the source, provide a link to the Creative Commons licence, and indicate if changes were made. The images or other third party material in this article are included in the article's Creative Commons licence, unless indicated otherwise in a credit line to the material. If material is not included in the article's Creative Commons licence and your intended use is not permitted by statutory regulation or exceeds the permitted use, you will need to obtain permission directly from the copyright holder. To view a copy of this licence, visit http://creativecommons.org/licenses/by/4.0/. The Creative Commons Public Domain Dedication waiver (http://creativeco mmons.org/publicdomain/zero/1.0/) applies to the data made available in this article, unless otherwise stated in a credit line to the data. 
settings in which ambulance crews are not trained in i.v. catheter placement [9].

Prior to the beginning of this study, studies on i.m. uptake of TXA had only been conducted in healthy volunteers $[8,10,11]$, whereas the patients eligible for TXA are in haemorrhagic shock or pre-shock [1]. Haemorrhagic shock leads to disturbances of skeletal muscle microcirculation, and muscular uptake of TXA is likely to be inhibited $[12,13]$ Therefore, we wanted to explore whether i.m. administered TXA provides sufficient uptake during haemorrhagic shock to achieve fibrinolysis-inhibiting serum concentrations.

Accordingly, the aims of this study were (1) To determine the impact of shock on the pharmacokinetics of i.m. TXA, and (2) to compare the pharmacokinetics of i.v. versus i.m. TXA in ongoing shock.

\section{Methods \\ Model}

Norwegian landrace pigs $(\mathrm{n}=18)$, weighing $42-50 \mathrm{~kg}$ were used in the present study. Both male and female pigs were used, and assigned at random. All male pigs were castrated. The model consisted of animals primarily utilised in emergency trauma surgery courses, where surgical teams train in stabilisation of trauma patients. The courses, arranged by the Northern Norway Regional Health Authority has the following arrangement: The instructor inflicts intraabdominal injuries, and as the course progresses adds more and more injuries to the intra- and retro-abdominal organs, before finally inflicting intrathoracic injuries. The anaesthesia team attempts to stabilise the swine through administration of clear fluids, and noradrenaline.

\section{Animal preparation}

The pigs were anesthetized directly at the farm, $10 \mathrm{~min}$ by car transport from the University lab. Anaesthesia was induced by azaperone $40 \mathrm{mg}$, ketamine $1000 \mathrm{mg}$ and atropine $1 \mathrm{mg}$ intramuscularly. After a peripheral ear vein catheter was established and $100 \mathrm{mg}$ ketamine and $200 \mathrm{mg}$ pentothal given i.v., pigs underwent tracheal intubation with an O.D. $7 \mathrm{~mm}$ tube and mechanically ventilated using a volume-controlled-ventilation (VCV), with a tidal volume of $10-15 \mathrm{~mL} / \mathrm{kg}$, rate of 20 per min. and a PEEP of $0 \mathrm{~cm} \mathrm{H}_{2} \mathrm{O}$. Inspiratory pressure was automatically adjusted by the ventilator to maintain tidal volume limits and to maintain an arterial $\mathrm{pH} 7.34-$ 7.40. After intubation, anaesthesia was continued with intravenous infusion of morphine $2 \mathrm{mg} / \mathrm{kg} / \mathrm{h}$, midazolam $0.15 \mathrm{mg} / \mathrm{kg} / \mathrm{h}$ and pentobarbital $4 \mathrm{mg} / \mathrm{kg} / \mathrm{h}$ a. An arterial line for invasive pressure monitoring was placed in the right carotid artery. A pulse oximeter was placed on the ear, for continuous monitoring of peripheral oxygen concentration, and ECG-electrodes for continuous heart rate monitoring. The depth of anaesthesia was regularly controlled by Federation of European Laboratory Animal Science (FELASA)-certified qualified anaesthesia personnel. Pigs that were alive at the end of the experiment and emergency trauma course, were euthanised by pentobarbital $300 \mathrm{mg}$, morphine $10 \mathrm{mg}$, and potassium chloride $50 \mathrm{mmol}$.

\section{Experimental protocol}

The animals were divided into three groups. A control group, Group 1 (i.m., non-shock), without injury or surgery, received $15 \mathrm{mg} / \mathrm{kg}$ TXA $(100 \mathrm{mg} / \mathrm{mL})$ intramuscularly in the proximal, right thigh, immediately after establishment of the invasive lines. This group received no surgery. Group 2 (i.v., shock) received $15 \mathrm{mg} / \mathrm{kg}$ TXA intravenously as a bolus in the peripheral ear vein catheter, $1 \mathrm{~h}$ after the start of surgery. Group 3 (i.m., shock) received $15 \mathrm{mg} / \mathrm{kg}$ TXA intramuscularly in the proximal, right thigh, $1 \mathrm{~h}$ after the start of surgery. Start of surgery was defined as the time of first incision by the trauma course instructor. The animals were allocated to i.m. or i.v. at the beginning of the course, prior to surgery, and with the allocator blind as to which surgical team was assigned to which animal. For the consecutive day of the course, the teams that had operated on animals in group 2 were set to operate on an animal from group 3 and vice versa. The surgical teams were blinded to the administration form of TXA.

Blood samples (2 $\mathrm{mL}$ full blood) were drawn prior to administration of TXA and at 5, 15, 25, 25, 45, 60 and $85 \mathrm{~min}$. The samples were stored on Eppendorf tubes and set to coagulate for $1 \mathrm{~h}$, before being cooled and centrifuged at $2500 \times g$ for $7.5 \mathrm{~min}$. The obtained plasma was frozen at $-20{ }^{\circ} \mathrm{C}$ prior to LC-MS/MS analysis. A general overview of the experimental protocol is provided as a flowchart in Fig. 1.

\section{Quantification of TXA concentrations}

Quantification of TXA in serum was performed with liquid chromatography tandem mass spectrometry (LCMS/MS). Stock solutions of $726 \mu \mathrm{g} / \mathrm{mL}$ TXA (Toronto Research Chemicals Inc. Ontario, Canada) was prepared in methanol: $\mathrm{H}_{2} \mathrm{O}$ (1:1) (Honeywell ${ }^{\mathrm{TM}}$ Riedel-de Häen ${ }^{\mathrm{TM}}$, Seelze, Germany) and stored at $-40{ }^{\circ} \mathrm{C}$. A 7-point calibration curve was prepared by dilution of the stock solution with serum at the following concentrations: 94, 47, 9.4, 4.7, 0.94, 0.094 and $0.016 \mu \mathrm{g} / \mathrm{mL}$. An internal standard solution was prepared by adding TXA- $-{ }^{13} \mathrm{C} 2,{ }^{15} \mathrm{~N}$ (Toronto Research Chemicals Inc. Ontario, Canada) to Milli-Q water (Millipore SAS, Molsheim, France) to a final concentration of $0.79 \mu \mathrm{g} / \mathrm{mL}$. 


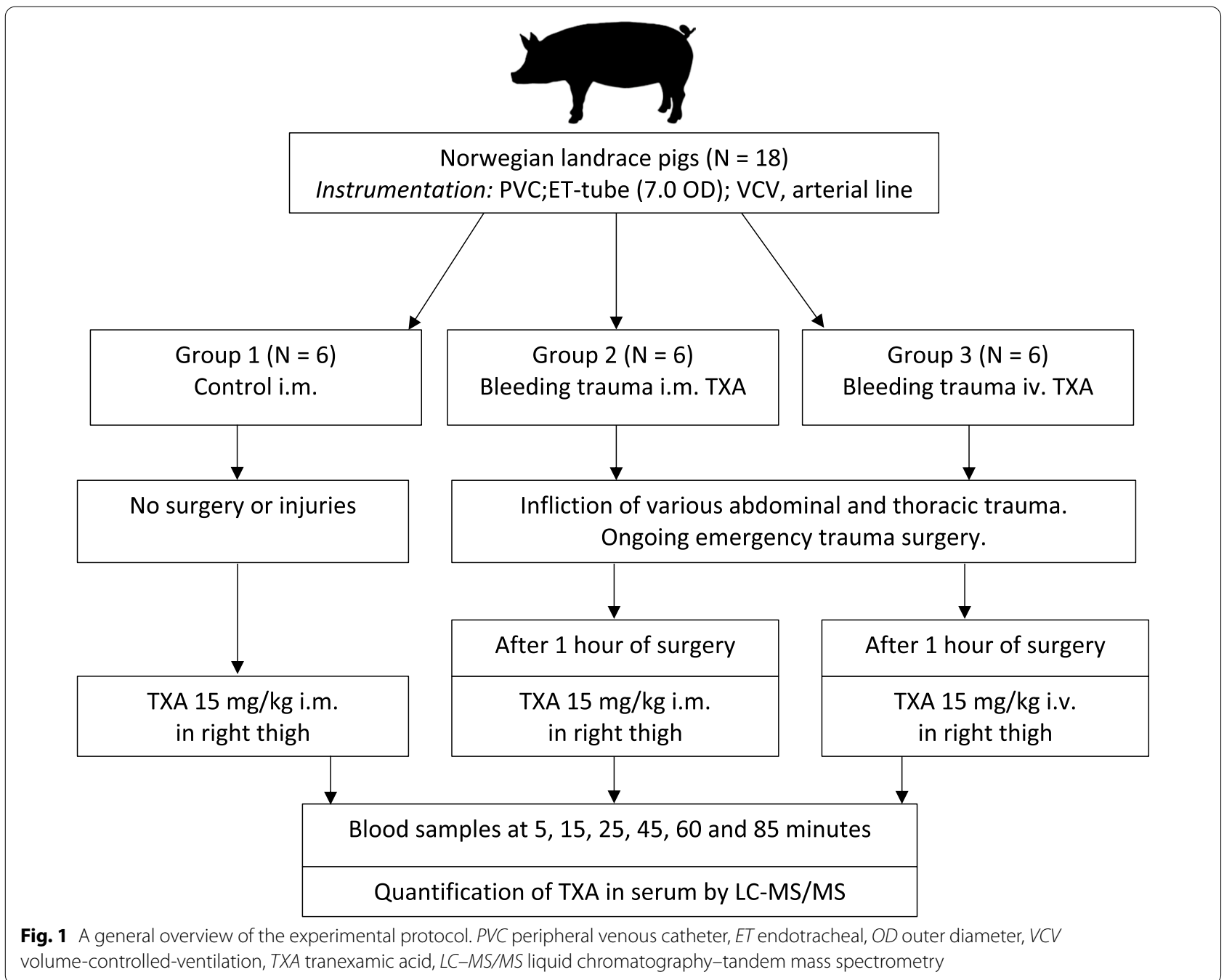

Serum samples and spiked standards were prepared as follows: $50 \mu \mathrm{L}$ sample, $50 \mu \mathrm{L}$ internal standard solution and $700 \mu \mathrm{L}$ methanol were mixed $(5 \mathrm{~s}$.) and centrifuged at $21,380 \times g$ for $4 \mathrm{~min}$. (Hettich Micro 200 centrifuge, Germany). $100 \mu \mathrm{L}$ of supernatant was transferred to LC-vials. Samples were analysed by LC-MS/ MS using a Waters Acquity UPLC I-Class FTN system with an autosampler and a binary solvent delivery system (Waters, Milford, MA) interfaced to Waters Xevo TQ-XS benchtop tandem quadrupole mass spectrometer (Waters, Manchester, UK). The mass spectrometer was operated in positive electrospray ion mode $(\mathrm{ES}+)$ and spray voltage was set to $0.85 \mathrm{kV}$. The system was controlled by MassLynx version 4.2 software. Desolvation gas temperature was $550{ }^{\circ} \mathrm{C}$; source temperature was $150{ }^{\circ} \mathrm{C}$; desolvation gas flow was 1000 $\mathrm{L} / \mathrm{h}$; cone gas flow was $150 \mathrm{~L} / \mathrm{h}$; collision gas pressure was $4 \times 10^{-3} \mathrm{mBar}$ (argon) and the ion energies were $0.5 \mathrm{~V}$ for both quadrupoles. The chromatography was performed on a $2.1 \times 100 \mathrm{~mm}$ Waters Acquity Cortecs ${ }^{\circledR}$ T3, $1.6 \mu \mathrm{m}$ column maintained at $50{ }^{\circ} \mathrm{C}$. The injection volume was set to $0.1 \mu \mathrm{L}$. Eluent A consisted of $0.1 \%$ formic acid (Sigma-Aldrich, St. Louis, MO) in water; eluent B consisted of $0.1 \%$ formic acid in methanol. Gradient elution was performed with $1 \%$ B hold until $0.5 \mathrm{~min}$ and a linear increase to $70 \% \mathrm{~B}$ until $2 \mathrm{~min}$, a linear increase to $98 \% \mathrm{~B}$ until $2.5 \mathrm{~min}$, and re-equilibration until 3.6 min with $1 \% \mathrm{~B}$ with a flow rate at $0.30 \mathrm{~mL} / \mathrm{min}$. Column temperature was maintained at $50{ }^{\circ} \mathrm{C}$ and autosampler temperature was set to $4^{\circ} \mathrm{C}$. For quantitative analysis of TXA, the following multiple reaction monitoring (MRM) transitions were used (bold transitions are qualifiers): $\mathrm{m} / \mathrm{z} 158 \rightarrow 123 / 95$ and $161 \rightarrow 125 / 96\left(\right.$ TXA and TXA- $\left.{ }^{13} \mathrm{C} 2,{ }^{15} \mathrm{~N}\right)$,

The method was validated and found to be linear from 0.005 to at least $94 \mu \mathrm{g} / \mathrm{mL}\left(r^{2}>0.998\right)$ Lower limit of quantification (LLOQ) was found to be $0.0025 \mu \mathrm{g} /$ $\mathrm{mL}(0.1 \mu \mathrm{L}$ injection volume). Between-day coefficient 
of variation (CV) for TXA was $<10 \%$ on four consecutive days. $\mathrm{CV}$ for intraday precision value was $<6 \%$ and was calculated by assaying three samples (low, medium and high concentration) six times on the same day. Accuracy for recovery test was $94.2-106.2 \%$ (6 levels, $\mathrm{n}=3$ for each).

\section{Statistical analysis}

Results are presented as mean \pm standard deviation. Assessment for whether data were distributed normally was performed using Shapiro-Wilk test. Changes from start of the experimental protocol in hemodynamic variables and from peak TXA serum concentrations $\left(C_{\max }\right)$, were compared by One-way repeated measures ANOVA. Problems with registering hemodynamic data from a few pigs distributed among the three groups, caused that hemodynamic average values are based on available data, on which statistical analysis was performed. When data were not normally distributed, repeated measures ANOVA on ranks was used. When significant differences were found, Dunnett's method was used to compare values within group vs. baseline. Differences in TXA serum concentrations and hemodynamic variables between groups were analysed by a One-Way Analysis of Variance test followed by an all-pairwise multiple comparisons procedure using Tukey's test. Repeated measures ANOVA on ranks and Dunn's test was used, when data were not normally distributed. Differences were considered significant at $p<0.05$. Data are presented as mean \pm standard deviation.

\section{Ethics}

The research animals were registered in the Norwegian Food Safety Authority's audit and applications system (Forsøksdyrsforvaltningens tilsyns- og søknadsystem, FOTS), and their use approved by the Norwegian Food Safety Authority (FOTS application number 15492) and the named animal care and welfare officer (Person med særskilt kontrollansvar, PMSK).

\section{Results}

A total of 18 pigs were studied. The non-shock i.m. (Group 1), the i.v. shock group (Group 2), and the i.m. shock group (Group 3), all included 6 animals each.

Heart rate, mean arterial pressure, diastolic blood pressure and systolic blood pressure were measured in all groups, as shown in Figs. 2 and 3. No significant changes occurred within groups during the experimental protocol. During experiments, the control group had significantly lower heart rate than the i.m. shock group, apparent already at administration, where heart rate was 85 beats per minute in the control group and 154 beats

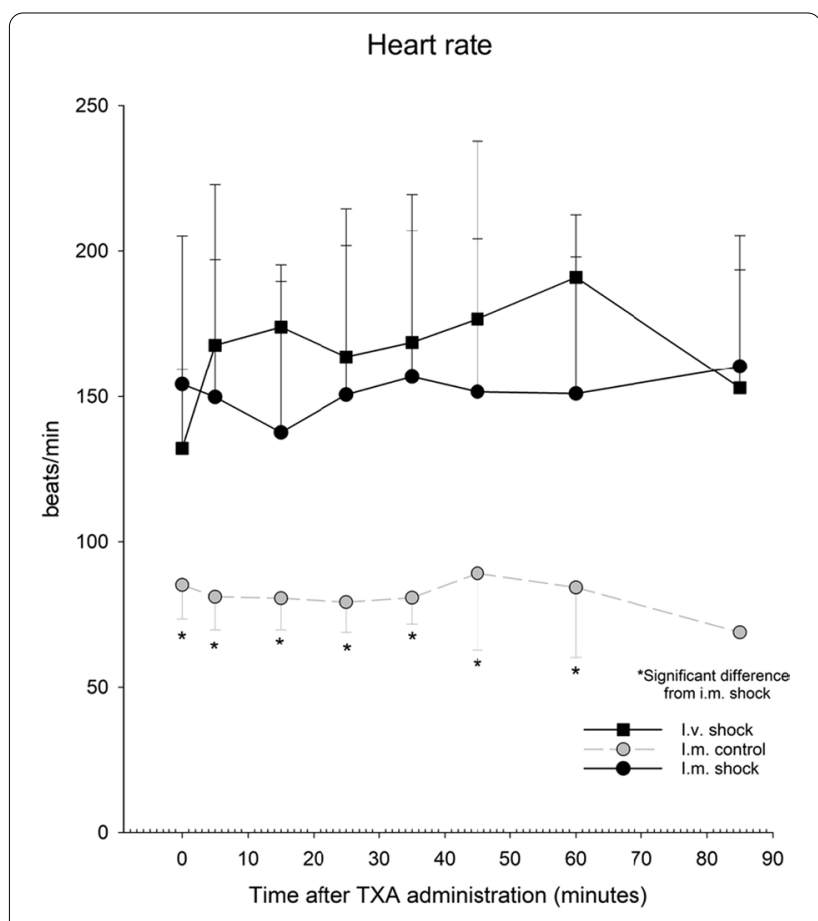

Fig. 2 Heart rate during experiments in the three groups. *Significant difference from i.m. shock group

per minute in the i.m. shock group. Calculating shock index (heart rate/systolic blood pressure) showed significantly lower values in the control group, as shown in Fig. 4.

In Group 1, mean maximum serum concentration was $36.9 \mu \mathrm{g} / \mathrm{mL}$ and occurred after $15 \mathrm{~min}$. In Group 2 the mean maximum serum concentration was $48.1 \mu \mathrm{g} / \mathrm{mL}$ and occurred after 5 min. In group 3 mean maximum serum concentration was $20.9 \mu \mathrm{g} / \mathrm{mL}$ and occurred after $15 \mathrm{~min}$. The temporal development of the serum concentration of TXA for the three groups are shown in Fig. 5, along with the lower end of the range in which TXA has been shown to have full effect in previous in vitro studies [3-5].

I.v. administration of TXA (group 2) resulted in $\mathrm{C}_{\max }$ after $5 \mathrm{~min}$, with significantly higher serum concentration compared to group 3. Subsequently, group 1 serum concentrations decreased significantly, already at $15 \mathrm{~min}$, and remained equal to the i.m. groups throughout the remaining experimental protocol.

Both i.m. groups (1 and 3) reached $C_{\max } 15$ min after administration. In the control group (1), TXA serum concentration was significantly reduced after $85 \mathrm{~min}$, while in group 3 serum concentrations remained stable from $15 \mathrm{~min}$ throughout the protocol. 


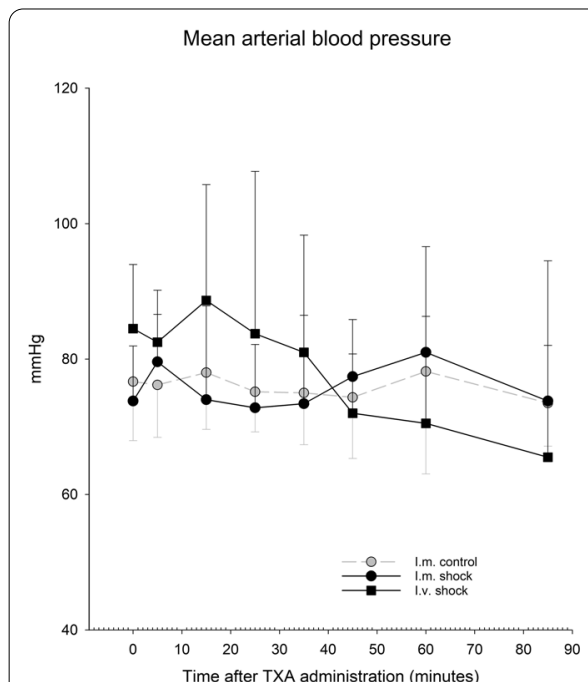

Fig. 3 Blood pressure $(\mathrm{mmHg})$ during experiments in the three groups. Mean arterial pressure (MAP) was calculated from systolic (SBP) and diastolic (DBP) blood pressure: $\mathrm{MAP}=[\mathrm{SBP}+2(\mathrm{DBP})] / 3 .{ }^{*}$ Significant difference from i.m. shock group

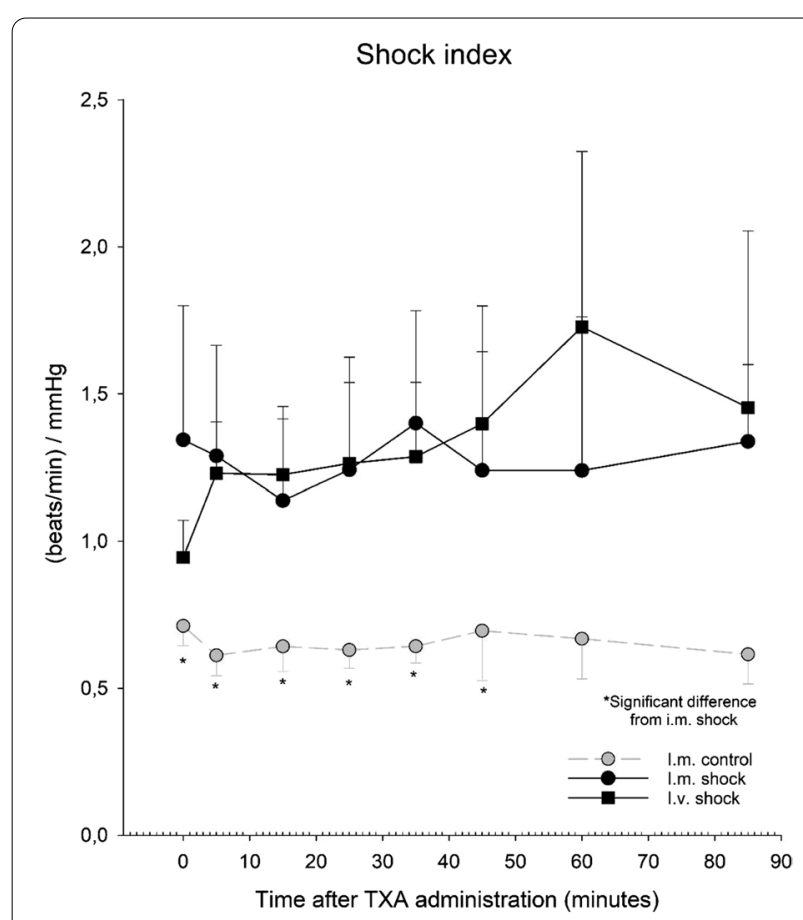

Fig. 4 Shock index (SI) was calculated from heart rate (HR) and systolic blood pressure (SBP): SI=HR/SBP. *Significant difference from i.m. shock group

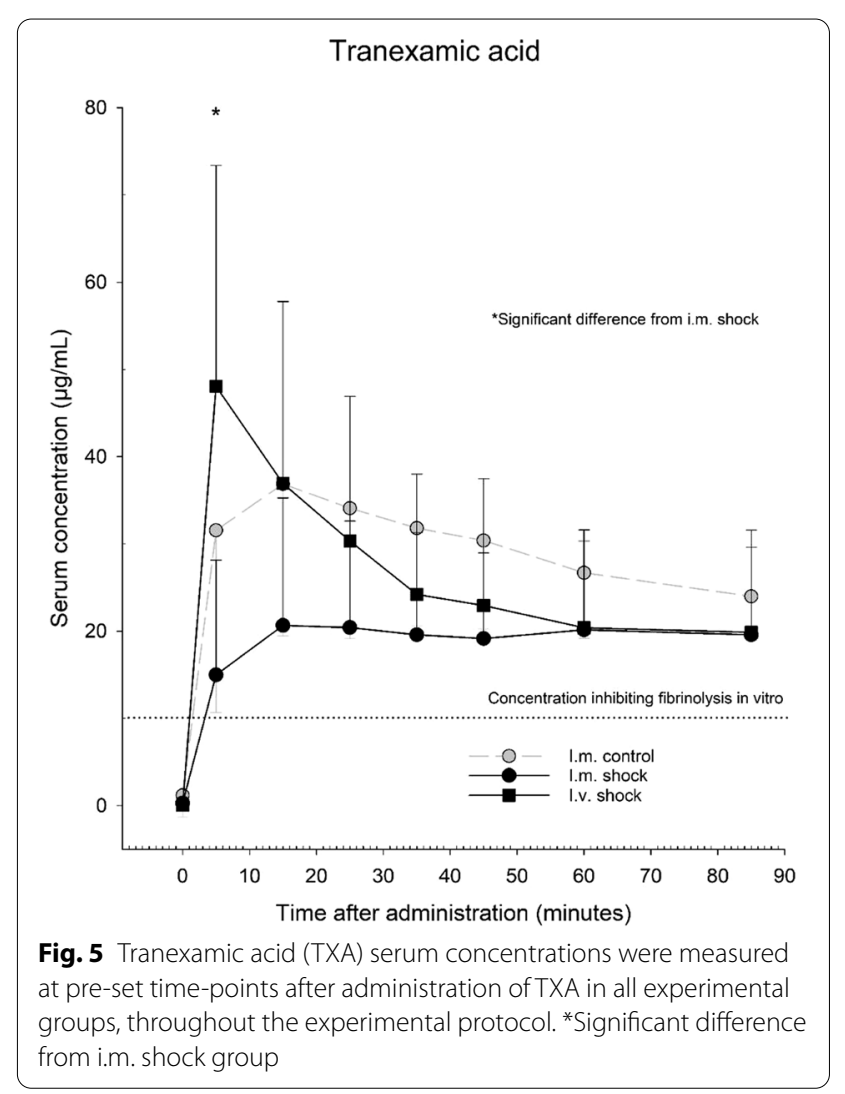

\section{Discussion}

The aims of this study were to determine the impact of shock on the pharmacokinetics of TXA when administered intramuscularly, and to compare the 
pharmacokinetics of i.v. and i.m. TXA administration in shock. We found that shock impaired muscular uptake of TXA, giving a lower $\mathrm{C}_{\max }$, but did not affect the time to $\mathrm{C}_{\max }$. As expected, intravenous TXA resulted in a higher $\mathrm{C}_{\max }$. However, within 60 min following i.v. administration, serum concentrations fell to corresponding levels of TXA administered intramuscularly. TXA administered intramuscularly in shock, reached $\mathrm{C}_{\max }$ at a serum concentration $20 \mathrm{ug} / \mathrm{mL}$ after $15 \mathrm{~min}$, but thereafter kept a steady level throughout the $85 \mathrm{~min}$ protocol.

The serum concentrations of TXA needed to fully inhibit fibrinolysis, has been reported by in vitro studies to be in the range of $10-17.5 \mathrm{ug} / \mathrm{mL}$, maybe even as low as $5 \mathrm{ug} / \mathrm{mL}$ [3-5]. In the present study, serum concentrations were above $10 \mathrm{ug} / \mathrm{mL}$ at all times, even after $5 \mathrm{~min}$ in shocked animals where TXA was administered intramuscularly. Further, in the shocked animals, serum TXA levels remained around $20 \mathrm{ug} / \mathrm{mL}$ throughout the protocol. Extrapolating to a clinical context; this suggests that TXA-treatment will achieve rapid effect if administered i.m., even in shocked patients.

Our study suggests that i.m. administration of TXA can serve as an alternative to i.v. administration. Given that i.v. administration has a quicker Cmax and retains higher concentrations the first $60 \mathrm{~min}$, this should still be the standard form of administration. However, in certain situations with restraints on time or training for i.v. catheter placement, and lack of equipment for intraosseous access, i.m. administration may be an option. This might be advantageous in some military or low-resource settings [9].

Our findings are comparable to those of a recent study by Spruce et al. In a swine model, they found similar pharmacokinetics of TXA administered i.v. and i.m. under haemorrhagic shock [14]. However, their study reported mean TXA serum concentrations of 40-60 ug/ $\mathrm{mL}$ after i.m. administration with only slightly higher doses of TXA (average $17 \mathrm{mg} / \mathrm{kg}$ against $15 \mathrm{mg} / \mathrm{kg}$ in this study). The difference may probably be attributed to the fact that Spruce et al. divided the doses of TXA in two portions, and administered one half-dose in each thigh [14]. Although it is also possible that the injuries inflicted on the animals in the present study lead to more severe shock compared to the controlled haemorrhage of Spruce et al. [14].

In an even more recent study by Grassin-Delyle et al., i.m. TXA was given to bleeding trauma patients, being the first study to do so [15]. TXA was first given as a $1 \mathrm{~g}$ i.v. bolus, followed by $1 \mathrm{~g}$ i.m., They found that therapeutic concentrations of i.m. TXA were reached within 4-11 min, which is comparable to our findings. Among their 30 included patients, they found no difference in absorption between shocked and non-shocked patients
[15]. Our findings show an initial trend towards lower serum concentrations in shocked compared to nonshocked animals receiving i.m. TXA but no significant differences were detected.

Another possible implication of our finding is the prolonged, and stable effect of i.m. administration. TXA is administered as a $1 \mathrm{~g}$ iv. bolus followed by infusion of $1 \mathrm{~g}$ for a duration of $8 \mathrm{~h}$ [1]. In settings with limited infusion pumps, an i.v. bolus followed by an i.m. "depot", may be an acceptable alternative to a bolus followed by i.v. infusion. This is in line with the findings of the both Spruce et al. and Grassin-Deyle, and further underpinned by Grassin-Delyle et al. reporting no adverse effects from i.m. administration among their patients $[14,15]$

\section{Limitations}

The main limitation of the study is the choice of model, where we have used swine primarily utilised for emergency trauma surgery courses. As a result, injuries, blood loss, and fluid resuscitation strategy, were not standardised. Despite this, the trends in the data were consistent. Unlike the animals in this study, most patients receiving TXA in trauma are not under general anaesthesia. General anaesthesia may influence muscular uptake of TXA [16]. The reduction of sympathetic tone may mitigate some of the negative effects shock has on muscle perfusion, and the study may underestimate the uptake compared to non-anesthetised, shocked patients. But at the same time anaesthesia itself has been shown to impair microcirculation of skeletal muscle, and may itself impair i.m. uptake [16]. Additionally, this study is limited to assess the achieved serum concentrations of TXA. And have not investigated that effect on fibrinolysis through biomarkers or viscoelastic tests. In vitro-studies reports full effect of TXA at serum levels from 5 to $17.5 \mathrm{ug} / \mathrm{mL}$ [3-5]. Viscoelastic tests from stable patients also suggests that maximum lysis inhibition is achieved somewhere below $10 \mathrm{ug} / \mathrm{mL}$ [17]. Even so, assessing whether the higher serum TXA concentrations achieved by i.v. administration translates to a superior inhibition of fibrinolysis would be of interest for future studies.

\section{Conclusion}

We found that shock impaired muscular uptake of TXA, but even in shocked pigs, serum concentrations reached effective levels within $5 \mathrm{~min}$ of administration. Thus, i.m. administration of TXA may be an alternative to i.v. and intraosseous administration during stabilisation and transport to advanced medical care.

\section{Acknowledgements}

We would like to thank the staff at the animal experimental facility (AniLab), Nord University, for all their hard work that made this study possible; regional trauma coordinator, Terje Lillegård, for permission to make use of the 
emergency trauma surgery courses for research purposes; and dr. Erle Lysfjord Sommerli for assisting in data collection.

\section{Authors' contributions}

H.K.B. conceived of the study, participated in design, collected data, and wrote the manuscript. O.M.F. performed laboratory analyses and co-wrote the manuscript. E.W.N. provided the lab facilities, and co-wrote the manuscript E.S.D. participated in design, performed the statistical analyses, and co-wrote the manuscript. All authors read and approved the final manuscript.

\section{Funding}

This study was funded by grants from the Odd Berg Groups Medical Research Foundation; the Laerdal Medical Foundation; and the Institute for Promotion of Anaesthesiological Research.

\section{Availability of data and materials}

All relevant data are available upon reasonable request from the corresponding author.

\section{Declarations}

\section{Ethics approval and consent to participate}

The research animals were registered in the Norwegian Food Safety Authority's audit and applications system (Forsøksdyrsforvaltningens tilsyns- og søknadsystem, FOTS), and their use approved by the Norwegian Food Safety Authority (FOTS application number 15492) and the named animal care and welfare officer (Person med særskilt kontrollansvar, PMSK).

\section{Consent for publication}

Not applicable.

\section{Competing interests}

The authors declare they have no competing interests.

\section{Author details}

${ }^{1}$ Department of Anaesthesia and Critical Care, University Hospital of North Norway, 9038 Tromsø, Norway. ${ }^{2}$ Department of Traumatology, University Hospital of North Norway, Tromsø, Norway. ${ }^{3}$ Department of Health and Care Sciences, Faculty of Health Science, UiT, The Arctic University of Norway, Tromsø, Norway. ${ }^{4}$ Division of Diagnostic Services, University Hospital of North Norway, Tromsø, Norway. ${ }^{5}$ Department of Anaesthesia and Critical Care, Nordland Hospital, Bodø, Bodø, Norway. ${ }^{6}$ University Nord, Bodø, Norway. ${ }^{7}$ Department of Immunology, University of Oslo, Oslo, Norway. ${ }^{8}$ Institute of Clinical Medicine, UiT, The Arctic University of Norway, Tromsø, Norway. ${ }^{9}$ Experimental and Clinical Pharmacology, Department of Medical Biology, UiT, The Arctic University of Norway, Tromsø, Norway. ${ }^{10}$ Center for Psychopharmacology, Diakonhjemmet Hospital, Oslo, Norway.

Received: 31 August 2021 Accepted: 29 November 2021 Published online: 18 December 2021

\section{References}

1. CRASH-2 trial collaborators, Shakur H, Roberts I, Bautista R, Caballero J, Coats T, et al. Effects of tranexamic acid on death, vascular occlusive events, and blood transfusion in trauma patients with significant haemorrhage (CRASH-2): a randomised, placebo-controlled trial. Lancet. 2010;376:23-32

2. Okamoto S, Hijikata-Okunomiya A, Wanaka K, Okada Y, Okamoto U. Enzyme-controlling medicines: Introduction. Semin Thromb Hemost. 1997;23:493-501.

3. Fletcher DJ, Blackstock KJ, Epstein K, Brainard BM. Evaluation of tranexamic acid and $\varepsilon$-aminocaproic acid concentrations required to inhibit fibrinolysis in plasma of dogs and humans. Am J Vet Res. 2014;75:731-8.

4. Yee BE, Wissler RN, Zanghi CN, Feng C, Eaton MP. The effective concentration of tranexamic acid for inhibition of fibrinolysis in neonatal plasma in vitro. Anesth Analg. 2013;117:767-72.
5. Picetti R, Shakur-Still H, Medcalf RL, Standing JF, Roberts I. What concentration of tranexamic acid is needed to inhibit fibrinolysis? A systematic review of pharmacodynamics studies. Blood Coagul Fibrinolysis. 2019;30:1-10.

6. Gayet-Ageron A, Prieto-Merino D, Ker K, Shakur H, Ageron FX, Roberts I, et al. Effect of treatment delay on the effectiveness and safety of antifibrinolytics in acute severe haemorrhage: a meta-analysis of individual patient-level data from 40138 bleeding patients. Lancet. 2018;391:125-32

7. CRASH-2 collaborators, Roberts I, Shakur H, Afolabi A, Brohi K, Coats T, et al. The importance of early treatment with tranexamic acid in bleeding trauma patients: an exploratory analysis of the $\mathrm{CRASH}-2$ randomised controlled trial. Lancet. 2011;377:1096-101.

8. Sano M, Hakusui H, Kojima C, Akimoto T. Absorption and excretion of tranexamic acid following intravenous, intramuscular and oral administrations in healthy volunteers. Rinsho yakuri/Jpn J Clin Pharmacol Ther. 1976;7:375-82.

9. Culligan WB, Tien HC. Tranexamic acid autoinjector for prehospital care of noncompressible hemorrhage. J Trauma Inj Infect Crit Care. 2011;71:S501-2.

10. Puigdellivol E, Carral ME, Moreno J, Plà-Delfina JM, Jané F. Pharmacokinetics and absolute bioavailability of intramuscular tranexamic acid in man. Int J Clin Pharmacol Ther Toxicol. 1985;23:298-301.

11. Grassin-Delyle S, Semeraro M, Foissac F, Bouazza N, Shakur-Still H, Roberts I, et al. Tranexamic acid through intravenous, intramuscular and oral routes: an individual participant data meta-analysis of pharmacokinetic studies in healthy volunteers. Fundam Clin Pharmacol. 2019;33:670-8.

12. Gierer P, Vollmar B, Schaser KD, Andreas C, Gradl G, Mittlmeier T. Efficiency of small-volume resuscitation in restoration of disturbed skeletal muscle microcirculation after soft-tissue trauma and haemorrhagic shock. Langenbeck's Arch Surg. 2004;389:40-5.

13. Wang P, Hauptman JG, Chaudry IH. Hemorrhage produces depression in microvascular blood flow which persists despite fluid resuscitation. Circ Shock. 1990;32:307-18.

14. Spruce MW, Beyer CA, Caples CM, Desoucy ES, Kashtan HW, Hoareau $\mathrm{GL}$, et al. Pharmacokinetics of tranexamic acid given as an intramuscular injection compared to intravenous infusion in a swine model of ongoing hemorrhage. Shock. 2020;53:754-60.

15. Grassin-Delyle S, Shakur-Still H, Picetti R, Frimley L, Jarman H, Davenport $\mathrm{R}$, et al. Pharmacokinetics of intramuscular tranexamic acid in bleeding trauma patients: a clinical trial. Br J Anaesth. 2021;126:201-9.

16. Bozkurt M, Kulahci Y, Zor F, Sen H, Acikel CH, Deveci M, et al. Comparison of the effects of inhalation, epidural, spinal, and combined anesthesia techniques on rat cremaster muscle flap microcirculation. Microsurgery. 2010;30:55-60.

17. Kammerer T, Groene P, Sappel SR, Peterss S, Sa PA, Saller T, et al. Functional testing for tranexamic acid duration of action using modified viscoelastometry. Transfud Med Hemother. 2021;48:109-17.

\section{Publisher's Note}

Springer Nature remains neutral with regard to jurisdictional claims in published maps and institutional affiliations.

\footnotetext{
Ready to submit your research? Choose BMC and benefit from:

- fast, convenient online submission

- thorough peer review by experienced researchers in your field

- rapid publication on acceptance

- support for research data, including large and complex data types

- gold Open Access which fosters wider collaboration and increased citations

- maximum visibility for your research: over $100 \mathrm{M}$ website views per year
}

At BMC, research is always in progress.

Learn more biomedcentral.com/submissions 